\title{
THE ANALYSIS OF LEARNING STRATEGIES FOR CHARACTER DEVELOPMENT OF STUDENTS DURING COVID-19 PANDEMIC
}

\author{
Hasan Asy'ari Najmuddin1a, Lenny Aprilianty ${ }^{2 b}$ \\ 1)Universiti Kebangsaan Malaysia; ${ }^{2}$ STIKES Mataram, NTB, Indonesia \\ a)Landah995@gmail.com; b) bzzatuljannah0110@gmail.com
}

\begin{abstract}
Nowadays, Indonesia is still experiencing pandemic issues or the Covid-19 virus outbreak. All the learning activities are suspended temporarily. The purpose is to contain the pandemic outbreak spreading and infection can be ceased. The education issues emerge due to conventional (face to face) or offline learning process is suspended. The rise of social and moral distortion occurred shows the need for improvement in early character-building education. The role of an educational institution is very required in improving Nation's morality through Character Education using a learning strategy adjusted to pandemic conditions. This is qualitative research with a study case in Anak Tangguh Mataram School by interview, thorough discussion, and observation. The analysis result shows that learning strategy is conducted by collaborating online and offline which integrating character values in every lesson material. Another one is by habituation method in the school or at home in instilling and developing student's character. And synergy must be performed among the school administrator, chaplain, parent, and society in instilling and developing education character in Anak Tangguh Mataram School.
\end{abstract}

Keywords: Character, learning, strategy, pandemic, students

\section{INTRODUCTION}

The country that is infected with the pandemic or commonly known as COVID-19 or Corona Virus Disease 2019 is about 200 nations in the world, so that, the death case due to the disease is enormous and keep on increasing (Khan et al., 2020). The pandemic is reported first time in Wuhan City, Hubei Province, China. The disease is caused by Severe Acute Respiratory SyndromeCoronavirus 2 or SARS-CoV-2 (Li et al., 2020). The COVID-19 disease is stated by the World Health Organization (WHO) as a global pandemic (Cucinotta \& Vanelli, 2020). All of the aspects of life are changed rapidly due to the impact of this pandemic. Almost every area of life must implement health protocol, including education (Anderson, 2020). 
The pandemic is very much affecting education in every nation in the world and as we know it that education is the most crucial field. Every government is thinking hard to find a solution on how to overcome the pandemic outbreak and cease its spread. Therefore, to break the COVID-19 pandemic spread, whereas the student can be as the carrier and the host without symptoms. All of the nation's abolish activities in the school. The number of students in the world who are required to study at home is estimated at more than 400 million (Domenico et al., 2020).

Character comes from the Latin language, i.e. "kharakter," kharasssein," and kharax," which means "tools for marking, "to engrave," and pointed stake". It is said this word starting to use in France as 'caractere' in the $14^{\text {th }}$ century. When it was absorbed in English the word 'caractere' transforms into 'character'. Later on, in Indonesian, the word 'character' also transforms into 'karakter' (Agus Wibowo, 2013). The term character derives from Greek language which means "to mark," i.e. to mark on someone's action or behavior. Afterward. The term is widely used in France as "caractere" in the $14^{\text {th }}$ century and then absorbed into English as "character", which eventually assimilated into Indonesian as "karaker".

As an identity or true self, a character is a basic value behavior as a reference in the interaction among humans. Universally, the various characters are formulated as a common life value based on the pillar of peace, respect, cooperation, freedom, happiness, honesty, humility, love, responsibility, humbleness, tolerance, and unity (Muhlas Samawi, 2017). Character is the most urgent and prominent part of someone's life, including students in our homeland. Character is an issue that has never been resolved for a long time ago and remains urgent to be built and discussed by every circle. The first reason is, a character is the most prominent of the various aspects attached to someone. Secondly, a person's character may change and be influenced by a situation or an event that occurred around someone or society's environment. Thirdly, the character can change because of someone's 
physical and non-physical factors toward individual or community lifestyle which regarded as relatively strange or new to the person (Majid, 2014).

The character describes a nation, identifier as well as a differentiator of a nation with another nation. The character provides direction on how the nation steps its foot in and through an era and delivering it to a certain degree. A great nation is a nation that has a character that can build a grand civilization and then influences world development (Muwafik, 2002). Thomas Lickona explains a complete definition of a character. A good character in Lickona's view includes knowledge on morals, and then arousing a will (commitment) toward moral feeling, and finally really perform good deeds (moral action) (Tutuk Ningsih, 2015). In other words, a character refers to a set of cognitive knowledge, attitudes, motivations, and skills. The relation between the three dimensions is seen in the following Figure on positive character features shaped moral knowledge, moral feeling, and moral action. The education process and outcome can determine the quality of human resources as reported by Hidayat \& Patras (2013). Highly qualified human resources are determined by the expected education process and implementation. The effort to build character education is also conducted by making an honest canteen, this honesty canteen is failed because most students are not honest. Hence, character education must be built by exemplary, combining attitude and behavior corresponding to their age. This can be conducted with the student's conformity to the school rules, learning process, and extracurricular (Gurning \& Laura, 2014; Andayati, 2012; Santosa, 2010).

Inadequate character education is caused by the poor school management. School planning in developing character is poorly executed. Besides, the problem in character education in the school is because it does not have an example or a role model teacher (Triatmanto, 2010; Adawiah, 2016). Student's capacity improvement in identifying the good and the bad in the actual condition is the objective of character education (Salahudin, 2013). The effect of implementation in educational institutions has not been completed yet 
proving the success and knowledge character (Agboola \& tsai, 2012; Kamaruddin, 2012). Winton (2008) comments that the focus of education character of the individual that will make culture, economy, and political institution great and perpetuate the status quo. Kisby (2017) has explained that the perspective toward character education is particularly related to individual moral behavior that is expressed in their life and he suggested that the focus of character education lies on the personal ethic instead of public ethic. So does Walsh (2018), he reports that the proponent of character education admits that social context is very important, but they conclude that it is easier to change individual than society.

Boyd (2010) criticizes the character education program by stating that mostly the works of literature on character education that is conservative in conceptual, empirical, moral, and politic are diverging in education. Character education as proposed by Bull \& Allen, (2018) and Taylor (2018) they deliver the idea that character education focuses on individual character influenced by its reading and education character serves conservative social agenda and liberal in the economy. Judith Suissa (2015) analyzes the rise of character education in England by eliminating political influence. The character education program has changed political ideas through their approach and language. Walsh (2018) claims that the focus of character education has a structural role in social, political, and economic. Meanwhile, Kisby (2017) argues that the proponent of character education fails to differentiate between the good people and the good citizen.

The crisis in morality is still a task to be done in education currently. The process of early character education must be planned thoroughly in elementary school education, especially during the Covid-19 pandemic. The role of elementary education is very important in building and developing character education in Indonesia. Considering the elementary education is the foundation to further educational structure. This study tries to analyze the character learning strategy in Anak Tangguh Mataram Integrated Islamic 
Kindergarten (TK IT) and Integrated Islamic Elementary School (SD IT) during the Covid-19 pandemic times.

\section{Method}

This study is qualitative research using a study case in Anak Tangguh Mataram Integrated Islamic Kindergarten (TK IT) and Integrated Islamic Elementary School (SD IT) in Indonesia. The study investigates character education developed that focuses on strategy in learning and habituation activities. The activities emphasize the aspect of events, activities, and processes within character education that is carried out by an individual or a group (Gall et al. 2003). The data collection technique were conducted using interview, observation, and thorough discussion directly (face to face) with the school administrator, teachers, or the chaplain, data was collected and analyzed specifically, afterward it was concluded. Generally, data were analyzed using an interactive model. It begins with the data collecting process, after that, it is compiled, decoded, put into categories, illustrated in a matrix, later on, it is drawn conclusion and verification. The data verification was conducted using descriptions based on the existing findings (Miles et al. 2014).

\section{Result and Discussion}

The Anak Tangguh Mataram School is an Integrated Islamic School that was founded in 2015. This educational institution is established under the Daarut Tahfidz Quran Foundation. The first education program is the Al-Quran Education Park (TPQ) and the Integrated Islamic Kindergarten (TK IT) for Tangguh Children, then the Integrated Islamic Elementary School (SD IT) was only formed in 2018. The vision of Anak Tangguh Mataram School is to forming Al-Quran memorizers with tough personality and future leaders.

The mission of the the Anak Tangguh Mataram School is to present educators with Islamic personalities (mindset and attitude patterns that are in accordance with Islam) so that they can become good role models for students. 
Prepare educators who understand the potential of the child and direct it appropriately according to the child's age and level of thinking. Developing a curriculum based on Islamic aqidah as a reference in the teaching and learning process. Making faith and manners a solid foundation so that they can form an Islamic personality in students. Bringing the Qur'an closer to students through tahfidz - tahsin and integrating it in all subjects (tsaqofah Islam and science). Using the method of talaqqiyan fikriyyan in the learning process so that students are able to understand and practice the knowledge gained. Train students to be leaders so that the spirit of leadership emerges and is directed to lead with Islam. Synergizing the role of parents and teachers and schools in shaping the resilient children of their time. The strategy carried out by the Anak Tangguh Mataram School in building character in students is in learning activities and habituation activities. During this pandemic, learning activities were carried out in 2 methods, namely online and offline. Online learning using the zoom application and what App video call. Offline learning is provided by making study groups that are limited to students' homes. Face-to-face or offline learning still follows the Health protocol established by the government. Implementation of offline learning only once a week.

\section{Learning Activities}

Implementing character education at the Anak Tangguh Mataram School is all of the teacher's responsibilities. Learning activities are carried out online and offline, during the Covid-19 pandemic. Based on the discussion result with the teacher Ummu Izzatuljannah, the TK IT managing teacher in Anak Tangguh Mataram explains that:

"The learning process is conducted online and offline. Online learning is given in the form of assignments and discussions through the Zoom application. And the offline learning was given by visiting home per study group. It consists of 5 or 6 students. The offline and online activities are scheduled in integrated. Character learning for the student is integrated into every lesson subject so that the teacher is expected to become a good example for the student" 
So does with the interview with one of the managing teachers in Anak Tangguh Mataram SD IT, i.e Ahdiati says:

"Online learning follows the Ministry of Education directives to stay using the application in learning such as Zoom. Later on, offline learning using parents' house in the living room or family studying room on the veranda or on the front side of the house, in Lombok language it is called 'berugak' by applying valid health protocol. The group division is based on the closest student's house location with its group's mate."

Online learning in Anak Tangguh Mataram using Zoom application or WhatsApp video call. The strategy carried out is by making a learning schedule for one semester. The schedule is expanded in every subject and explained it's every learning target or objective. 2 days before teaching, the teacher or the chaplain tells information on the Zoom link to be used in the learning and discussion. Students who do not have a hand phone or devices can join with their friends as long as implementing health protocol. Before learning online, they are given assignments related to the lesson material learned. The assignment purpose is that the student has prepared themselves to follow learning through Zoom. The assignment is given usually related to daily activity themes such as how to pray, how to clean the house, how to help parents, and so forth. The main purpose is to build a strong 'Tangguh' student's character.

Every student will get their turn in offline learning. It means the offline learning concept by visiting the student's house will have many advantages. While offline learning is conducted twice a week, according to the consent. The benefit obtained is, first, the students can be arranged to keep on social distancing and wearing a face mask because the group consisted of 5 or 6 students. Second, the learning process and control is more maximum with lesser student amount. Third, direct communication with the student's parents that get their visit turn. Direct communication or visiting (silaturahmi) is very important to know the character development and improvement in a student's daily life. Four, evaluating every student's learning outcome during a visit to the home by synergizing with their parents. 
Character education in Anak Tangguh Mataram School is integrated within-subject lessons. In the subject, it introduces good character values and the importance of the values. Besides making the pupil achieving the targeted competency (material), it is also designed to make the pupil in knowing, understanding/caring, and internalizing those values, and taking it as behavior. This corresponds to the data obtained based on an interview with the class teacher, that the teacher understands that akhlakul karimah education described through character education values such as religiosity, honesty, tolerance, discipline, hard work, creativity, independence, curiosity, passion for nationalism, loving homeland, acknowledging achievement, friendly/communicative, loving peace, fondness to read, caring environment, caring social, responsibility taught to the pupil in teaching-learning process in order the students can apply in their daily life, in the school environment, and in their residence as well as growing to fulfill their desired aim.

Character education emphasizes the aspect of attitude, value, and the nature of the student, so in its formation, it must be started with the teacher. In this case, how every educational institution, both formal and non-formal, can generate the teacher as a good role model. The teacher in Anak Tangguh Mataram School tries entirely to become a good role model (uswah hasanah) for the pupil so that the teacher will not have difficulty cooperating with the student, co-teacher, parents, and surrounding neighborhood. The covid-19 pandemic situation becomes the trigger for the teacher to make a pandemicbased lesson plan. The lesson plan is the initial stage for the teacher to make teaching preparation because with good preparation, it can ease in teaching implementation and increase study outcome. One of the forms in teaching preparation is by preparing a Lesson Plan or known as RPP and prepares a media if it is necessary. Since the finding of character education in the learning activities at Anak Tangguh Mataram School, it is designed to build the value of religiosity, tolerance, social caring, environmental caring, fond to read, independence, and responsibility. 


\section{Habituation Activity}

Character education implementation in Anak Tangguh Mataram School is conducted by habituation. The habituation process is carried out by the student and the teacher through the learning process. The habituation process is carried out during the online or offline learning. As expressed by Muslimah, one of the teachers in Anak Tangguh TK IT, she said that:

"Character education by habituation practice is given in the assignment or homework process. The student is given a practice assignment according to the lesson subject and recorded in video or picture. The picture and video are reported and evaluated by the teacher of the lesson."

Baiq Dwi Suci is one of the teachers in Anak Tangguh SD IT also says that:

'The habituation process in building students' character is one of the strategies conducted in Anak Tangguh Mataram School. During the Covid19 period, it is given by an assignment to build a good habit character by recording it in video and image. And later on, when visiting or offline in once a week, it is used as an evaluation and establishment process".

The planning of habitual activity is adjusted responding to the pandemic condition. The habituation activity through online learning is conducted in each students' houses and recorded in video and pictures. The assignment outcome of the photo and video is sent to the WhatsApp group of each student. The teachers see the students' assignment outcome in building and developing students' character. During a face to face learning or offline, the students' assignments are appreciated and given input to increase the students' enthusiasm to be even better.

Based on the finding in the field, habituation planning activity in Anak Tangguh Mataram School was made and adjusted corresponding to the school's vision and mission. Habituation is the process of forming attitudes and behavior that stay automatically if conducted repeatedly. Habituation activity in the school and at the home including routine activity, spontaneous activity, planned activity, and exemplary activity. From the finding, the learning activity 
in Anak Tangguh Mataram School aims to instill the values of religiosity, honesty, discipline, loving in the homeland, tolerance, social caring, environmental caring, fondness to read, independence, and responsibility.

First, routine activity is a regular activity conducted repeatedly either in the school or in the home, the aim is to familiarize the pupil to be better. Character education planning in the school is made of indicators mentioned in the school rules and codes. Second, spontaneous activity is an activity that is not bound to a specific time and place. Character education planning in spontaneous activity at the school is made of the indicators mentioned in the rules. And third, planned activity is conducted gradually adjusted to the fixed calendar and schedule. This activity objective is to familiarize the students with the school's activity, according to each of the fields. Character education planning within the planned activity in Anak Tangguh Mataram School is made through indicators included in the school's program. And lastly, exemplary activity is a daily activity that needs to be taken as an example. Character education planning in Anak Tangguh Mataram School within the exemplary activity is made through indicators included in the school rules and report.

Some researchers explain on character education studies. Ulger et al. (2017) report that three supporting components must be prepared by the school or education institution in developing a good character, they are excellent teachers, a specified curriculum, and a developed character value system. The competent teachers or chaplain as the role model or the real example in character education so does with the specific or excellent curriculum implemented in the school or education institution determines the success of character education that is expected by all of the stakeholders (Fahmy et al. 2015; Barghi et al. 2017). The school or education institution formulates a strategy to achieve character education values. The strategy carried out is by directing the teachers or the chaplain with the students' parents to collaborate and commit to getting involved in every program to achieve the targeted character education values. So does the strategy, it is a 
process of combining the vision and mission of the school or education institution, Policy and activity become one unity to achieve character education values (Greer, 2001).

The character education conducted in Anak Tangguh Mataram School is strengthened by the good school management. The very important indicators in character education are the improvement of religiosity, morality, and student leadership in the school. Religiosity level is the most visible indicator in character education in the school (Arthur, 2019). Forming student's or santri character education can be done through the learning process, standard process, content standard, and standard assessment must be met in the learning process. The purpose is that learning process in the character education values is expected can be achieved. The learning process in the school has fulfilled all the expected standards of character education.

The objective of character education in the school, especially in Anak Tangguh Mataram School is to form a noble character or the entire student morality. The student not only earned a good academic or intellectual knowledge but also emotional intelligence and high religiosity. The noble character education or morality is prioritized compared to the academic score in the form of numbers in the report. Just like Skaggs \& Bodenhorn's (2006) research, they report the study to find out the relation between the implementation of character education values on the students' behavior and study outcome. The result of the research shows that character education values are not significant in influencing student's study outcome and achievement.

\section{CONCLUSION}

Character education developed in Anak Tangguh Mataram School during Pandemic times remains, refer to the school's vision and mission. The vision and mission of the school are the core and guideline informing and developing character education. As for the strategy conducted in character education 
during the Covid-19 pandemic is by learning activity process and habituation activity. The learning activity is conducted online and offline, during the pandemic period. Firstly, character education online was given an assignment to the student and the outcome was sent to the teacher or chaplain for evaluation. The assignment is sent in the form of photos and videos that can educate and develop student's character. Secondly, offline learning, which makes a study group consisted of 5 or 6 students that are close to each other. The offline learning must follow a good health protocol. Later on, habituation activity that has been set by the school either routine, spontaneous, planned, and exemplary activities.

Learning and habituation activity is expected able to develop the value of religiosity, honesty, discipline, love in the homeland, tolerance, social caring, environmental caring, fondness to read, independence, and responsibility. All of the values will be instilled if there is synergy. The synergy is very much required both for the student's parents, the school's administrator, and the society in order character Education keeps to continue effectively and efficiently during the Covid-19 pandemic period.

\section{BIBLIOGRAPHY}

Agboola, A., \& Tsai, K. C. (2012). Bring character education into classroom. European Journal of Educational Research, 1(2), 163-170.

Anderson, J. (2020, March). Should schools close when coronavirus cases are still rare? Quartz.

Andayati, D. (2012). Kantin kejujuran berbasis teknologi informasi. Jurnal Teknologi Technoscientia, 4(2), 128-136.

Arthur, J. (2019). Christianity and the character education movement. History of Education, 48(1), 60-76. doi:10.1080/0046760X.2018.1506049.

Barghi, R., Zakaria, Z., Aswati, H. \& Hashim, N. H. (2017). Heritge education in the primary school standard curriculum of Malaysia. Teaching and Teacher Education, 61, 124-131. doi:10.1016/j.tate.2016.10.012. 
Bull, A., \& Allen, K. (2018). Introduction: Sociological interrogations of the turn to character. Sociological Research Online, 23(2), 1-7.

Boyd, D. (2010). Character education and citizenship education: A case of a cancerous relationship. Philosophy of Education Yearbook, 2010, 384392.

Cucinotta, D., \& Vanelli, M. (2020). WHO declares COVID-19 a pandemic. Acta Bio-Medica : Atenei Parmensis, 91(1), 157-160. https://doi.org/10.23750/abm.v91i1.9397.

Domenico, L. Di, Pullano, G., Coletti, P., Hens, N., \& Colizza, V. (2020). Expected impact of school closure and telework to mitigate COVID-19 epidemic in France.

Khan, M., Kazmi, S., Bashir, A., \& Siddique, N. (2020). COVID-19 infection: Origin, transmission, and characteristics of human coronaviruses. Journal of Advanced Research, 24, 91-98. https://doi.org/10.1016/j.jare.2020.03.005.

Li, C., Yang, Y., \& Ren, L. (2020). Genetic evolution analysis of 2019 novel coronavirus and coronavirus from other species. Infection, Genetics and Evolution, 82(March), $1-3$. https://doi.org/10.1016/j.meegid.2020.104285.

Fahmy, R., Bachtiar, N., Rahim, R., \& Malik, M. (2015). Measuring student perceptions to personal characters building in education: An Indonesian case in implementing new curriculum in high school. Procedia-Social and Behavioral $\quad$ Sciences, 211, 851-858, doi:10.1016/j.sbspro.2015.11.112.

Gurning, M. \& Laura, N. (2014). Implementasi pendidikan anti korupsi melalui warung kejujuran di SMP Keluarga Kudus. Jurnal Teknologi Pendidikan dan Pembelajaran, 2(1), 93-102.

Greer, C. R. (2001). Strategic human resource management: A general managerial approach (2ndEdition). Upper Saddle River, NJ: Prentice Hall. 
Gall, M. D., Gall, J. P. \& Borg, W. R. (2003). Educational research. Boston, MA: Pearson Education, Inc.

Hidayat, R., \& Patras, Y. E. (2013). Evaluasi sistem pendidikan nasional Indonesia. 2nd International Seminar on Quality and Affordable Education (ISCAE) (pp. 235-244).

Kamaruddin, S. A. (2012). Character education and students social behavior, Journal of Education and Learning, 6(4), 223-230.

Kisby, B. (2017). Politics is ethics done in public': Exploring linkages and disjunctions between citizenship education and character education in England. Journal of Social Science Education, 16 (3), 7-20.

Majid Abd, Pendidikan Berbasis Ketuhanan (Bogor: Penerbit Ghalia Indonesia, 2014).

Muwafik Akh. Saleh, Membangun Karakter dengan Hati Nurani (Jakarta:PT Erlangga, 2002).

Miles, M. B., Huberman, M. \& Saldana, J. (2014). Qualitative data analysis: A methods sourcebook. New York, NY: Sage Publication, Inc.

Ningsih Tutuk, Implementasi Pendidikan Karakter (Purwokerto: STAIN Press, Cet.I ,2015).

Samawi Mukhlas dan Hariyanto, Pendidikan Karakter, Bandung:Rosdakarya, ,Cet -VI,2017.

Santosa, P. I. (2010). Prototipe kantin tanpa uang berbasis kartu pintar. JUTI, 8(1), 27-32.

Salahudin, A. (2013). Pendidikan karakter. Bandung: Pusaka Setia.

Skaggs, G., \& Bodenhorn, N. (2006). Relationships between implementing character education, student behaviour, and student achievement. Journal of Advanced Academics 18(1), 333-345. doi: 10.4219/jaa-2006345.

Suissa, J. (2015). Character education and the disappearance of the political. Ethics and Education, 10(1), 105-117. 
Taylor, N. (2018). The return of character: Parallels between late-Victorian and twenty-first century discourses. Sociological Research Online, 23, $399-415$.

Triatmanto, T. (2010). Tantangan implementasi pendidikan karakter di sekolah. Cakrawala Pendidikan, 29(3), 187-203.

Ulger, M. Yigittir, S. \& Ercan, O. (2014). Secondary school teachers' beliefs on character education competency. Procedia-Social and Behavioral Sciences, 131(May), 442-449. doi:10.1016/j.sbspro.2014.04.145.

Walsh, G. (2018). Character education and social justice. Retrieved from https://curriculumfore quity.org/2017/10/01/character-educationand-social-justice.

Wibowo Agus, Manajemen Pendidikan Karakter Di Sekolah(Yogyakata:Pustaka Pelajar, Cet. I, 2013).

Winton, S. (2008). The appeal(s) to character education in threatening times: Caring and critical democratic responses. Comparative Education, 44(3), 305-316.

Zurqoni, Z., Retnawati, H., Apino, E., \& Anazifa, R. D. (2018). Impact of character education implementation: A goal-free evaluation. Problem of Education in the 21th Century, 76(6), 881-899. doi:10.33225/pec/18.76.881. 